\title{
Effective Silencing of Sry Gene with RNA Interference in Developing Mouse Embryos Resulted in Feminization of XY Gonad
}

\author{
Ning Wu, ${ }^{1,2}$ Ai-Bing Yu, ${ }^{3}$ Hua-Bin Zhu, ${ }^{2}$ and Xiu-Kun Lin ${ }^{1,2}$ \\ ${ }^{1}$ Institute of Oceanology, Chinese Academy of Sciences, No. 7 of Nanhai Road, Qingdao 266071, China \\ ${ }^{2}$ Institute of Animal Science, Chinese Academy of Agricultural Sciences, Beijing 100094, China \\ ${ }^{3}$ Laboratory of Animal Nutrition, Graduate School of Animal Science and Technology, Yangzhou University, \\ Yangzhou 225009, China \\ Correspondence should be addressed to Xiu-Kun Lin, iocas329@163.com
}

Received 30 August 2011; Accepted 15 October 2011

Academic Editor: Sanford I. Bernstein

Copyright () 2012 Ning Wu et al. This is an open access article distributed under the Creative Commons Attribution License, which permits unrestricted use, distribution, and reproduction in any medium, provided the original work is properly cited.

Delivering siRNA or shRNA into the developing embryos is still a main challenge to use of RNAi in mammalian systems. Here we analyze several factors influencing RNAi-mediated silencing of Sry gene, which is a tightly controlled spatiotemporal expressed gene and only shortly expressed in developing mouse embryo gonad. A Sry gene-specific shRNAs expression vector (pSilencer4.1/Sry565) was constructed. The shRNA constructs were mixed with polyethylenimines (PEIs) to form a complex and then injected into pregnant mice though tail vein. Our results showed that Sry gene was downregulated significantly in developing embryos. Further study revealed that knocking-down of Sry expression resulted in feminization of gonad development in mouse embryos and the expression level of Sox 9 and Wt1 gene was also significantly changed by downregulation of Sry. The transfection efficiency is associated with the amount of plasmid DNA injection, injection time, injection speed, and volume. Our studies suggest that transplacental RNAi could be implemented by tail vein injection of plasmid vector into pregnant mice.

\section{Introduction}

RNAi is a useful approach for discerning the role of genes in particular cell, tissue, or organism and also has potential applications in treatment of disease [1]. This evolutionary conserved pathway can be programmed to inhibit the expression of any genes by delivering small interfering RNA ( siRNA) with sequence that is complementary to the target mRNA [2]. RNAi has been used extensively to probe gene function in mammalian cells $[3,4]$. However, in contrast to the great success of RNAi in mammalian cell culture, there have been many challenges for use of RNAi in animal in vivo $[5,6]$, especially in developing embryos.

Delivery of siRNA to postimplantation-staged embryos continues to be a major limitation in the widespread application of this important technology. Information regarding the prenatal delivery of plasmid DNA (pDNA) comes largely from the gene therapy field where in utero gene targeting/therapy has been proposed as a method to treat diseases that affect the developing embryos [7], which may ultimately be the most effective mean to treat genetic defects. Various routes of pDNA delivery have been attempted for fetal "gene therapy" including direct injection of the fetus $[8,9]$, injecting into the placenta or umbilical cord, and injecting into the amniotic cavity or the yolk sac $[10,11]$. To obtain efficient results, precise techniques are needed for all of these manipulations. Intravascular delivery of naked DNA is increasingly recognized as a preferred route to deliver nucleic acids to target tissues [12]. Because of its simplicity and effectiveness, high levels of transgene expression can be achieved and sustained. The "tail vein injection" method had been widely used before, to allow expression of a variety of plasmids in the liver [13-15]; expression of a specific gene by the DNA can be observed within the first 24 hours and approximately $50 \%$ of hepatocytes express the transgene [13]. In recent years, tail vein injection has been employed 
to silence genes in neonatal [16] and adult mice [14], and several previous studies have validated "tail vein injection" method to deliver constitutively expressed short hairpin (sh) RNAs to pregnant mice during the postimplantation period of development, and knockdown of some specific genes could be observed in developing embryos [17, 18]. However, little is known if the approach could be used in silencing some spatiotemporal genes in developing embryos in vivo.

Sry is essential for initiating male sex differentiation in mammals $[19,20]$. In mice embryos, Sry exhibits a tightlycontrolled and limited spatiotemporal profile of expression in the precursors of Sertoli cells of XY gonad [21, 22]. Thus, Sry is likely to act as a trigger for a cascade of molecular and cellular events that direct the bipotential gonad to differentiate into a testis in a center-to-pole manner. Previous studies revealed that Sry was first detected in the genital ridge at 10.5 days following coitum $(\mathrm{dpc})$, shortly after the emergence of the genital ridges in mouse. After reaching peak levels of expression at $11.5 \mathrm{dpc}$, Sry is rapidly declined and extinguished shortly after $12.5 \mathrm{dpc}$. Sry is activated in a very short period in gonadal somatic cells, and it may trigger testis-specific genes to initiate testis differentiation $[23,24]$. Numerous additional genes, including Sox9 [2528], Wt1 [29-32], Dax1 [33], Sf1 [34], and Gata4 [35, 36], have been identified to be involved in this complex process. However, the direct target genes of Sry in vivo havenot been identified. Studies have shown that Sry expression level has to reach a certain threshold to induce testis development [37]. Insufficient expression of Sry results in abnormal testis development of XY embryos. In fetuses of XY Gata4/Fog2 null mutation mice, the Sry transcript levels are significantly reduced and result in abnormality in gonadgenesis [36]. XY sex reversal occurred when the Sry expression level reduced to $\sim 25 \%$ of the wild type. However, since the Sry gene is not been knockedout in developing embryos, the genes which regulated by Sry in sex differentiation have not yet been well documented. Further study is needed to address if inhibition of Sry in developing mouse embryos could result in sex reversal and abnormal embryo testis development.

In the present study, tail vein injection approach was employed to deliver the shRNA expression vector to knockdown Sry expression in developing embryos, and certain factors affecting the silencing of the target gene were investigated. Additionally, the development of male gonads with Sry silence phenotype was also presented, and the expression levels of several Sry-related sex determination genes were analyzed.

\section{Materials and Methods}

2.1. Experimental Animal. All animal experiments were performed in accordance with the International Guiding Principles for Biomedical Research. ICR mice were obtained from the Peking University Health Science Experimental Animals Center (Beijing, China). Five-week-old female mice were maintained and mated in a temperature and humidity controlled room with food and water ad labium. Each female mouse was injected with 5 IU PMSG (Sigma, St. Louis, MO). After 48 h, 5 IU HCG (Sigma, St. Louis, MO) was injected into the intraperitoneal cavity, and then paired with one male in the afternoon. Female mice with vaginal plugs were placed in separate cages in the next morning. The gestation age was defined as day after coitum (dpc).

2.2. Construct of siRNA Expression Vectors. pSilencer4.1$\mathrm{CMV} /$ neo vector (Ambion, CA) was used to construct the siRNA expression plasmids. For tracking the siRNA expression, we inserted an EGFP gene into the pSilencer4.1$\mathrm{CMV} /$ neo vector under the SV40 promoter to replace the neomycin gene. The EGFP gene was amplified by PCR using pEGFP-N3 (Clontech, CA) as template and then inserted to the NruI site and BclI site. The PCR was performed as the following condition: $94^{\circ} \mathrm{C}$ for $30 \mathrm{~s}, 60^{\circ} \mathrm{C}$ for $1 \mathrm{~min}$, and $72^{\circ} \mathrm{C}$ for $1 \mathrm{~min}$, followed by $10 \mathrm{~min}$ at $72^{\circ} \mathrm{C}$. The primers for amplifying EGFP are as follows: EGFPF, 5'ACTGATCAATCGCCACCATGGTGAGCAAG3', EGFPR, 5'AGATCGCGATTACTTGTACAGCTCGTCCA3'. Genespecific shRNAs target to Sry were ligated downstream of the CMV promoter. Our previous study has shown that one of the Sry-specific shRNA that target 565 to 585 site of Sry mRNA could significantly knock-down Sry gene expression [38]. The sequence of shRNA Sry 565-585 is as follows: GAT CCG CAG CAG TTT C AT GAC CACTTC AAG AGA GTG GTC ATG AA A CTG CTG CTT. The forward and reverse synthetic oligonucleotides were annealed and inserted into the Hind III and BamHI sites of the pSilencer4.1-CMV/neo vector to construct the shRNA expression vectors, pSilencer4.1/Sry565. Of note, pSilencer41-CMV/neo is a circular plasmid encoding a hairpin siRNA whose sequence is not found in the mouse, human, or rat genome database and could be used as an ideal negative control plasmid. A negative control vector, $\mathrm{pSi}$ lencer4.1/EGFP, was constructed in which Neomycin gene was replaced by EGFP cassette on pSilencer4.1-CMV/neo. The structure of shRNA expression vectors was shown in (Figure 1(a)).

2.3. Plasmids and PEI Micelles Complex Formation. Sry siRNA expression plasmid pSilencer4.1/Sry565 and negative control plasmid pSilencer4.1/EGFP were extracted by endotoxins-free plasmid extraction kit (Omega) and dissolved in sterile and free of endotoxins water; DNA concentration and quality was determined by spectrophotometer. The linear polyethylenimine (PEI, ExGen500, Mw 22, 000) was obtained from Fermentas (Canada). To synthesize the pDNA-PEI conjugate, pSilencer4.1/Sry565 (from 0.2 to $2.0 \mathrm{mg}$ ) or pSilencer4.1/EGFP (from 0.2 to $2.0 \mathrm{mg}$ ) were diluted in 0.1 to $1.0 \mathrm{~mL}$ of sterile $5 \%$ glucose solution, vortexing gently and spining down briefly. Meantime, dilute $15 \mathrm{mM}$ of ExGen 500 to sterile 5\% glucose solution (from $0.1 \mathrm{~mL}$ to $1.0 \mathrm{~mL}$ ). Vortex gently and spin down briefly. Then add the diluted ExGen 500 to the diluted DNA solution and vortex-mix the solution immediately. Twenty minutes incubation at room temperature was needed for pDNA/PEI micelles formation. 


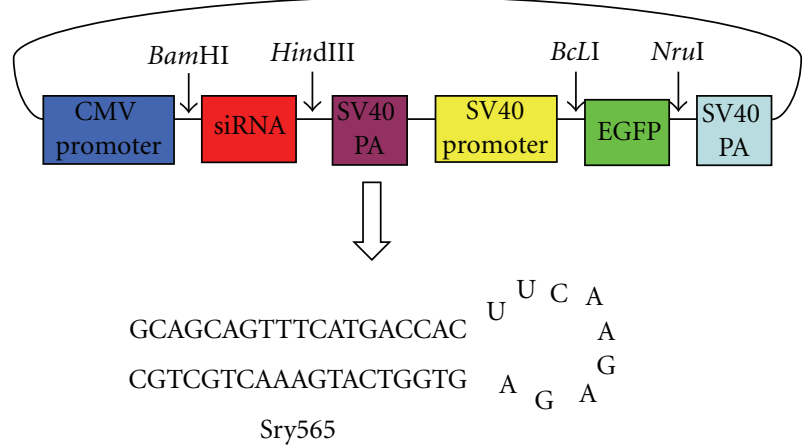

(a)

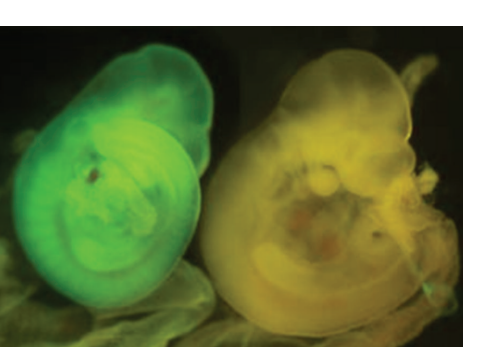

(c)

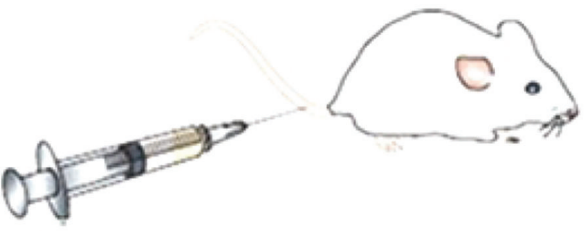

(b)

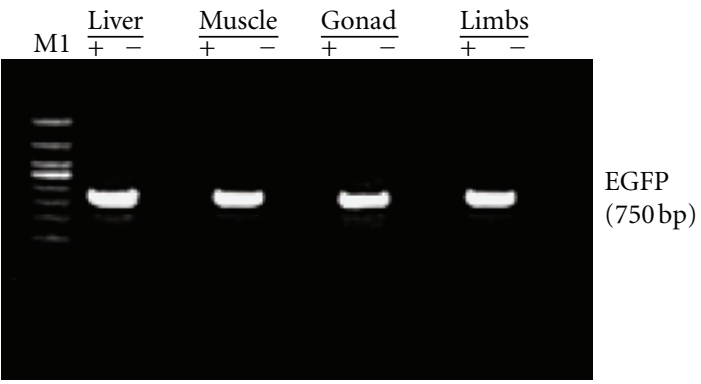

(d)

FIGURE 1: Schematic diagram of designing shRNAs expression vectors, and expression of siRNAs in embryos of pregnant mice. (a) Construction of shRNA expression plasmids. pSilencer4.1-CMV/neo vector was used as basic plasmid to construct the siRNA expression, plasmids pSilencer4.1/Sry565. The EGFP coding region was obtained from the pEGFP-N3 vector and cloned downstream of the SV40 promoter to replace the Neomycin gene to construct the plasmid. Gene-specific shRNAs (Sry565) or scrambled shRNA (not shown) were then ligated downstream of the CMV promoter. (b) Tail vein injection. The shRNA expression plasmids were delivered into pregnant mice though tail vein injection. (c) $11.5 \mathrm{dpc}$ embryos were dissected from the uterus, and deciduas and membranes were removed. Transmitted light and fluorescence images of embryos were recorded using a Nikon-inverted fluorescence microscope to determine the extent of GFP expression. The left embryo was injected with pSilencer4.1/Sry565. The right embryo was injected with 5\% glucose solution. (d) Analysis of EGFP expression in 11.5 dpc embryos. Semiquantitative RT-PCR was used to detect the GFP expression in different tissues, including liver, muscle, gonad, and limbs, in the absence $(-)$ or presence of $(+)$ pSilencer4.1/Sry565.

2.4. Tail Vein Injection. Tail vein injection in mice was performed as described by TE Gratsch et al. [17] with a little modification. Briefly, mice were warmed for $5 \mathrm{~min}$ using a heat lamp and a heating pad, and then siRNA expression plasmid (pSilencer4.1/Sry565) or negative control plasmid (pSilencer4.1/EGFP) was mixed with or without PEI micelles, injected into the tail vein of pregnant mice, respectively. To investigate the effects of injection time, speed, and volume on the transfection efficiency, 0.2 to $2.0 \mathrm{~mL}$ of pDNA/PEI micelles were injected with the injection speed range from 5 seconds to 30 seconds at $5.5 \mathrm{dpc}$ to $10.5 \mathrm{dpc}$.

2.5. Embryo Collection and Dissection. From 11.5 to $15.5 \mathrm{dpc}$, pregnant female mice were sacrificed by cervical dislocation and embryos were dissected immediately from the deciduas. Embryos at $10.5 \mathrm{dpc}$ to $12.5 \mathrm{dpc}$ were more accurately staged by counting the tail somites (ts) at the time of dissection [27]. Embryos with 12 ts ( \pm 2 ts) were the equal of $10.5 \mathrm{dpc}$, and 20 ts $( \pm 2 \mathrm{ts})$ were considered as $11.5 \mathrm{dpc}$, and those with 30 ts ( \pm 3 ts) were equivalent to $12.5 \mathrm{dpc}$. Embryos with $14.5 \mathrm{dpc}$ and $15.5 \mathrm{dpc}$ were staged by examining forelimb and hindlimb morphologies. Embryos showing GFP fluorescence in the urogenital system were selected for further analysis. Embryos were classified from weak to strong by GFP expression level in the urogenital system varied. The sex of embryos was genotypically identified by PCR as described previously [39]. The gonad/mesonephros complex dissected from each selected embryos were frozen in liquid nitrogen immediately and used for RNA or protein extraction to determine the expression level of Sry and GFP.

2.6. Real-Time RT-PCR. Sry and GFP transcript levels were determined on single pair of gonad/mesonephros complex obtained from individual fetuses using a quantitative RTPCR [40]. Briefly, total RNA was isolated from each single pair of gonad/mesonephros complex of male embryos using the RNA easy mini kit (QIAGEN, CA), and then reverse transcribed at $42^{\circ} \mathrm{C}$ for $1 \mathrm{~h}$ in a $50 \mu \mathrm{L}$ reaction mixture using the Moloney-Murine Leukaemia Virus Reverse Transcriptase (M-MLV-RT, Promege, CA) and oligo-dT15 primer. Quantitative RT-PCR was performed to detect the relative amount of mRNAs, including Sox9, WT1 (-KTS), WT1 (+KTS), Amh, Daxl, Sf1, and Gata4 as described previously [31]. Sequences of the primers used for PCR amplification 
TABLE 1: $11.5 \mathrm{dpc}$ Mouse embryos used to analysis of Sry knockdown. GFP expression was assessed macroscopically by examining whole urogenital systems under a dissecting microscope equipped with fluorescence optics. The density of GFP fluorescence was classified as low, medium, or high. Feminization was assessed by gonadal histology, immunofluorescent marker expression, or quantitative RT-PCR.

\begin{tabular}{lccc}
\hline Plasmid treated at the 9.5 dpc & $\begin{array}{c}\text { Number of embryos at 11.5 dpc } \\
\text { (both sexes) }\end{array}$ & $\begin{array}{c}\text { Number of embryos (both sexes) } \\
\text { showing high GFP expression }\end{array}$ & $\begin{array}{c}\text { Total number of feminized } \\
\text { males/males with high GFP }\end{array}$ \\
\hline 5\% glucose solution & $n=60$ & 0 & $0 / 27$ \\
pSilencer4.1/EGFP & $n=78$ & 40 & $0 / 18$ \\
pSilencer4.1/Sry565 & $n=320$ & 56 & $8 / 27$ \\
\hline
\end{tabular}

TABle 2: Primers used for real-time RT-PCR analysis.

\begin{tabular}{|c|c|c|}
\hline Genes & Primer name & Primer sequences $5^{\prime} \rightarrow 3^{\prime}$ \\
\hline \multirow{2}{*}{ Sry } & Sry-F & AGCTCTTACACTTTAAGTTTTGAC \\
\hline & Sry-R & GCAGCTCTACTCCAGTCTTGCC \\
\hline \multirow{2}{*}{$W t 1(-K T S)$} & $\mathrm{Wt1}(-\mathrm{KTS})-\mathrm{F}$ & TACCTTAAAGGGCCACGGTAT \\
\hline & $\mathrm{Wt1}(-\mathrm{KTS})-\mathrm{S}$ & GAAGGGCTTTTCACCTGTATGA \\
\hline \multirow{2}{*}{$W t 1(+K T S)$} & $\mathrm{Wt} 1(+\mathrm{KTS})-\mathrm{F}$ & GCTGGGAGCTCCAGCTCAGT \\
\hline & $\mathrm{Wt} 1(+\mathrm{KTS})-\mathrm{R}$ & GGGCTTTTCACTTGTTTTAC \\
\hline \multirow{2}{*}{ Sox9 } & Sox9-F & GGTGCTGAAGGGCTACGCTGGACG \\
\hline & Sox9-R & GGCTGGTACTTGTAATCGGGTGGTC \\
\hline \multirow{2}{*}{ Gata4 } & Gata4-F & CGAGGGTGAGCCTGTATGTAA \\
\hline & Gata4-R & TGGCCTGCGATGTCTGAGTG \\
\hline \multirow{2}{*}{ Amh } & Amh-F & TCCTACATCTGGCTGAAGTGATATGGGAGC \\
\hline & Amh-R & CTCAGGGTGGCACCTTCTCTGCTTGGTTGA \\
\hline \multirow{2}{*}{$S f 1$} & Sf1-F & TGGTGTCCAGTGTCCACCCTTAT \\
\hline & Sf1-R & TCCGTCACGTGTAATGCTTGT \\
\hline \multirow{2}{*}{$\operatorname{Dax} 1$} & Daxl-F & AGAGTATGCCTATCTGAAAGGGACCGTG \\
\hline & Daxl-R & ACGACATCGCTATTGATGAATCTCAGCA \\
\hline \multirow{2}{*}{$\beta$-actin } & $\beta$-actin-F & AACCCTAAGGCCAACCGTG \\
\hline & $\beta$-actin-R & CAGGATTCCATACCCAAGAAGG \\
\hline
\end{tabular}

of the relevant target genes are listed in Table 2. All samples were normalized against $\beta$-actin, using the comparative CT method $\left({ }^{\Delta \Delta} \mathrm{CT}\right)$. For each primer, standard curves were constructed to confirm amplification efficiency. Data was expressed as relative normalized expression level, where the value of gene expression in embryos treated with $5 \%$ glucose solution was normalized to the $\beta$-actin expression level and was defined at 1.0.

2.7. Testes Histological Section. The male embryos were fixed in Serra (ethanol: 37\% formaldehyde: acetic acid, $6: 3: 1$ ) for $24 \mathrm{~h}$, then embedded in paraffin, and sectioned to $7 \mu \mathrm{m}$. The embryo slices were stained with hematoxylin and eosin followed standard procedure and analyzed under microscope with magnified 200 times.

2.8. Statistics. Statistical analyses were performed using software from SPSS for Windows 13.0 (SPSS Inc., IL). All data was described as mean \pm SEM. Student's $t$-test was performed to analyze the two-tailed $P$ values. Differences were considered significant when $P$ value is less than 0.05 .

\section{Results}

As known, Sry is a tightly controlled and limited spatiotemporal expression gene, and its expression is first detected in the genital ridge at $10.5 \mathrm{dpc}$ and reaches peak levels of expression at $11.5 \mathrm{dpc}$, then the expression of Sry was declined rapidly and extinguished at $12.5 \mathrm{dpc}$.

shRNA expression vectors were delivered into more than 100 pregnant mice by tail vein injection at 6.5 to $9.5 \mathrm{dpc}$. Our results showed that $\sim 15 \%$ pregnant mice had abortion after injecting shRNA plasmids. To check the efficiency of shRNA transfection, a part of pregnant mice $(n=67)$ were sacrificed at $11.5 \mathrm{dpc}$, and total 320 embryos were collected. Our results revealed that the expression of GFP was found in the whole embryos (Figures 1(c) and 1(d)) without preference for tissue types (Figure $1(\mathrm{~d})$ ). These results suggested that tail vein injection is a useful approach to deliver the shRNA into the pregnant embryos.

In our next step, we tried to understand if the Sry expression was affected by the shRNA; quantitative RT-PCR and Western blotting analysis were performed to detect the Sry 


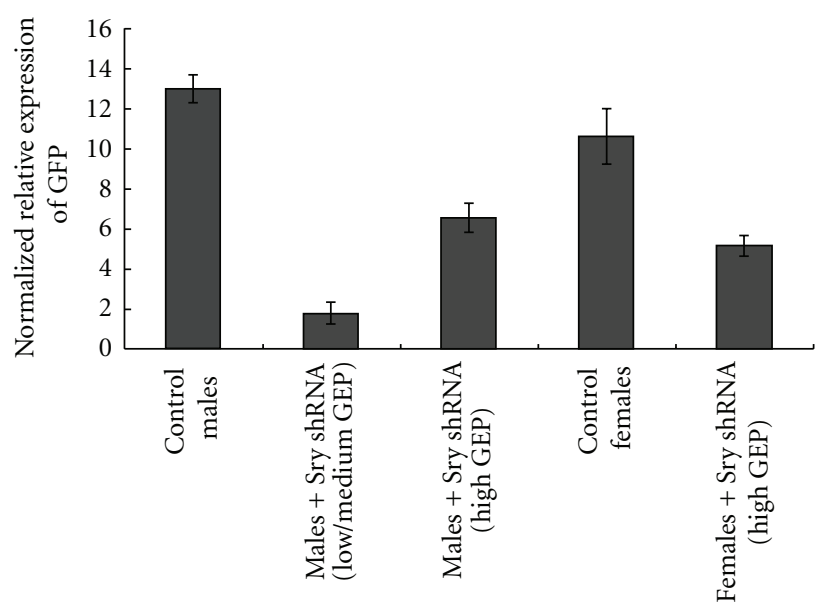

(a)

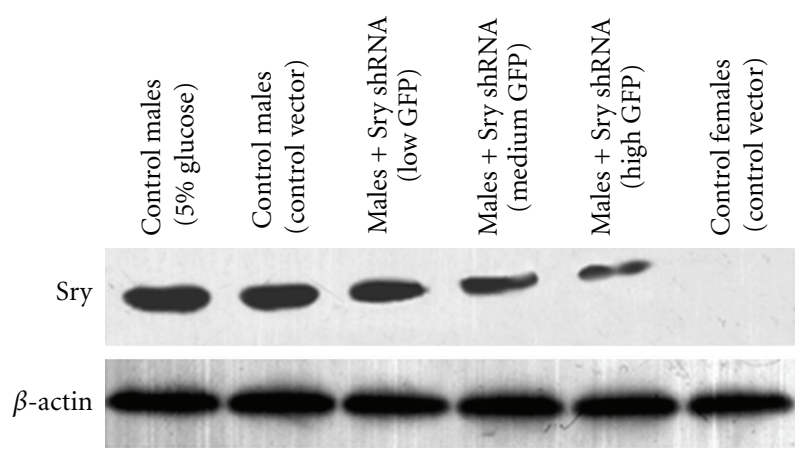

(c)

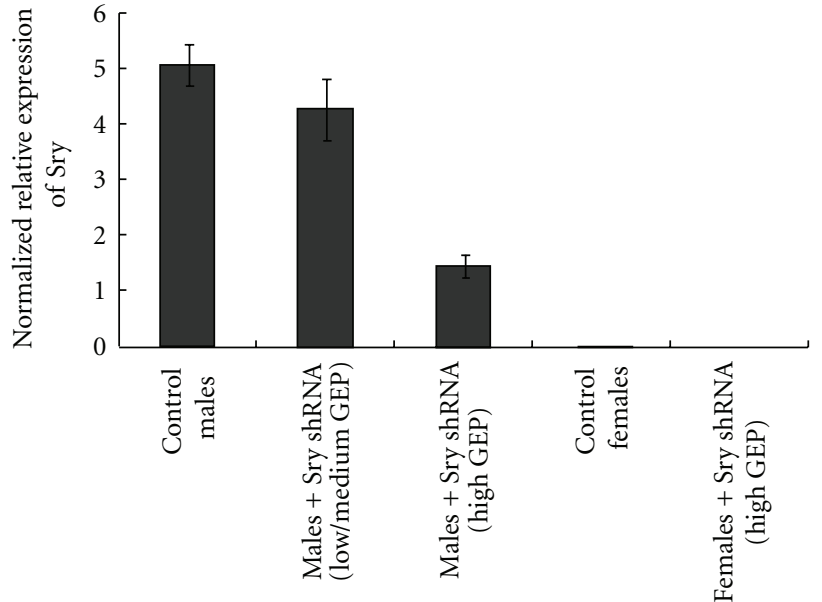

(b)

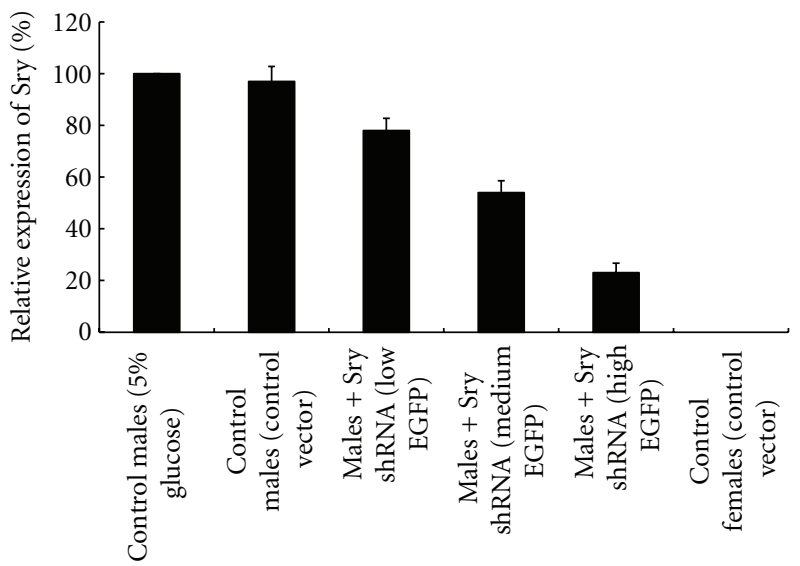

(d)

FIGURE 2: Quantitative RT-PCR and Western-blotting analysis to detect the expression of gonadal GFP and Sry expression in embryonic mouse gonads. Gonads at $11.5 \mathrm{dpc}$ were grouped on the basis of overall GFP expression observed at the macroscopic level. Quantitative RT-PCR was then carried out on grouped gonads. Gene expression was normalized to IL3 (autosomal in mouse) (mean \pm SEM; $n=3$ ). (a), Relative expression of GFP in embryos. Relative high level of GFP expression was found in controls, and variable expression levels of GFP in male and female gonads with Sry knockdown. (b) Sry expression in control and Sry knockeddown gonads. (c) Western-blotting analysis of Sry expression. Control males which treated with $5 \%$ glucose solution or negative control vector (pSilencer4.1/EGFP), males embryos treated with Sry shRNA (pSilencer4.1/Sry565) and with low, medium, or high GFP expression, and the control females treated with control vector and show high GFP expression were all collected at $11.5 \mathrm{dpc}$ and each gonad were separated for protein isolation. Western-blotting were performed to determine the SRY expression level in each group of embryos and $\beta$-actin was also be detected as a loading control. (d) Quantitative analysis of the Sry protein level. The expression of Sry was determined by Western blot. The value of Sry protein expression level was normalized to the $\beta$-actin expression level and the relative expression level of Sry in embryos which treated by $5 \%$ glucose solution was set at $100 \%$. Results are expressed as the mean \pm SEM, $(n>20)$.

level in certain embryos. The gonads were dissected from selected embryos, and green fluorescence was determined using a microscopic. Gonads were then classified into groups on the basis of their GFP expression level, which based at the macroscopic level: low, medium, or high. Quantitative PCR with reverse transcription (RT-PCR) analysis revealed an inverse correlation between gonadal GFP and endogenous Sry gene expression; Gonads with high levels of GFP showed significantly reduced Sry messenger RNA, whereas those with lower GFP gene expression showed modest Sry mRNA reduction (Figures 2(a) and 2(b)). Since the expression level of GFP represents expression of shRNA, our results confirmed that the shRNA could downregulate the Sry expression efficiently. Of note, male embryos with low or no GFP expression appeared normal (confirmed by histology or immunostaining) and were excluded from further analysis. Each group of embryos tested in the study were provide in Table 1. Western-blot analysis was performed to further confirm the interfering efficiency of shRNA, and the results showed that in the gonads with high level of GFP expression, the Sry was significantly reduced (Figure 2(c)). Treatment of the gonads with pSilencer4.1/Sry565 resulted in significantly inhibition of Sry protein expression in male embryos, and the inhibition rate reached 75\% (Figures 2(c) and 2(d)) 
compared with the male embryos treated with control plasmid, pSilencer4.1/EGFP, or treated with 5\% glucose solution. The results revealed that tail vein injection is an effective approach to interfering genes expression in developing embryos.

We next studied the factors affecting the transfection efficiency in developing embryos. In order to study if the PEI could enhance transfection efficiency, $1.0 \mathrm{mg}$ pDNA with or without PEI was delivered into pregnant mice at $9.5 \mathrm{dpc}$, respectively. Embryos were collected at day 11.5, and the transfection efficiency was determined by analyzing the GFP expression level using microscopy and RT-PCR. The potential toxic effects of our procedure on animals were assessed by measurement of mother mouse abortion rate or dead fetus rate. Our results confirmed that the transfection rate was significantly higher in embryos treated with pDNA/PEI complex than that treated with naked pDNA (Figure 3(a)). Additionally, PEI treatment did not increase the toxicity (Figure 3(a)). Higher transfection rate could be obtained when injecting pregnant mice with $0.8 \mathrm{mg}$ pDNA/PEI complex without toxicity (Figure 3(b)). Previous studies have shown that large volume with rapid injection usually resulted in a higher level of transgene expression [12]. We next studied the effect of injection volume and injection speed on transfection efficiency. However, we found that large volume with high injection speed always resulted in stresses, causing pregnant mice abortion; although high GFP expression was found to be increased in embryos with increasing injection speed (Figure 3(c)) and large injection volume (Figure $3(\mathrm{~d})$ ), abortion rate was also augmented with increasing the injection speed and volume (Figures 3(c) and $3(\mathrm{~d}))$. The optimum condition for delivering pDNA was as follows: $0.8 \mathrm{mg}$ of $\mathrm{pDNA} / \mathrm{PEI}$ with the volume of $1.0 \mathrm{~mL}$, injection speed, $10 \mathrm{~s}$. Since Sry is only expressed in a very short period in developing embryos, injection time is also a critical factor for gene silencing efficiency. We next studied the effects of injection time on the silence efficiency. We delivered $0.8 \mathrm{mg}$ of pDNA mixed with proper amount of PEI into 5 groups of pregnant mice at 5.5, 7.5, 8.5, 9.5, and $10.5 \mathrm{dpc}$, respectively. As shown in Figure 3(e), the silencing effect of Sry gene is closely related with the time of pDNA delivery; pDNA delivered in 5.5 and $7.5 \mathrm{dpc}$; embryos showed very weak GFP expression and embryos showed modest GFP expression and Sry gene reduction can be detected in $8.5 \mathrm{dpc}$ - and $10.5 \mathrm{dpc}$-treated group. Highly GFP expression and greatest Sry gene silencing were observed in embryos treated at $9.5 \mathrm{dpc}$ (Figure 3(e)).

To analyze the effects of reduction expression of Sry on male gonads development, the gonadal development in genetic male mice with Sry silencing was assessed by gonadal histology at $12.5,13.5$, and $15.5 \mathrm{dpc}$, respectively (Figure 4). Gonadal development in XY-gene-type embryos, treated with nonsilencing scrambled control shRNA expression vector (pSilencer4.1/EGFP) with high GFP expression was developing normally $(n=22)$ at $12.5,13.5$, and $15.5 \mathrm{dpc}$ (Figures 4(a), 4(d), and $4(\mathrm{~g}))$, and the XX gene type female embryo gonads treated with control vectors also developed normally (Figures 4(c), 4(f), and 4(i)). Testis cord could not be visualized in Sry silencing XY embryos at $12.5 \mathrm{dpc}$ (Figure 4(b)). In contrast, the testis cord could be visualized clearly in the male embryos treated with the control plasmid (Figure 4(a)). At $13.5 \mathrm{dpc}$, distinct testis cords could be found in the embryos treated with control plasmid (Figure $4(\mathrm{~d})$ ), whereas no sign of differentiation was found in the Sry knockdown male gonads (Figure 4(e)), with their gonads looking like the female ones (Figure 4(f)). Similar results can also be observed at $15.5 \mathrm{dpc}$ (Figure $4(\mathrm{~h})$ ). At $15.5 \mathrm{dpc}$, in the control male, the testes cords were developed completely in embryos untreated (data not show) or treated with control plasmid (Figure $4(\mathrm{~g})$ ), while the Sry knockdown male gonads showed female-like gonad with poorly organized cords (Figure $4(\mathrm{~h})$ ). These results indicated that testes development was inhibited in Sry silencing XY mice fetuses.

To further study the effect of Sry silence on the expression of sex determination cascade genes, we then checked the expression of several sex-related genes, including Wt1, Sox9, Sf1, Amh, Gata4, and Daxl at $11.5 \mathrm{dpc}$ by Quantitative RT-PCR in male embryos. Our results showed that the mRNA levels of Wt1 including Wt1 (-KTS) and Wt1 (+KTS) were significantly increased in Sry silencing embryos gonad compared to those in the control embryos (Figure 5(a)). Moreover, the expression level of Sox 9 which was thought to be the most likely target gene of Sry in the Sry cascade was decreased significantly (Figure 5(a)). Western blot analysis was performed to detect the changes of gene expression in protein level. As shown in (Figure 5(b)), WT1 (-KTS) and Wt1 (+KTS) expression levels in Sry knockdown XY gonads at $11.5 \mathrm{dpc}$ were increased. In contrast, the SOX9 expression level was significantly decreased (Figure 5(b)). However, no obvious change was found for Gata4, Sf1, Amh, and Dax1 in Sry silencing embryos gonad (Figure 5(a)).

\section{Discussion}

Over the past years, the specific gene silencing by RNAi have made great development. Recently, there were some reports on silencing postimplantation mouse embryo genes by RNAi, which offered an opportunity to investigate posttranscriptional characters of genes in developing embryos $[17,18,41]$. However, since Sry expression in the developing embryos only exists in a very short period, very little is known if it could be knocked-down using RNAi approach. In the present study, we used a systemic delivery method to deliver the shRNA expression vector of Sry into the developing embryos in pregnant mice through tail vein injection. Our study suggested that RNAi would be a powerful approach to study the function of the temporary expressing genes in postimplantation-stage developing embryos.

The hydrodynamic injection technique to deliver siRNA to certain tissues has been used to demonstrate that siRNAmediated RNAi could occur in adult mammals [42]. Since then, several reports have appeared using the technique to deliver siRNA to various organs in mice and rats. Due to its easy manipulation and high efficiency, the hydrodynamic tail vein (HTV) injection method has been used for delivery of nucleic acids to various organs and more successfully to liver. 


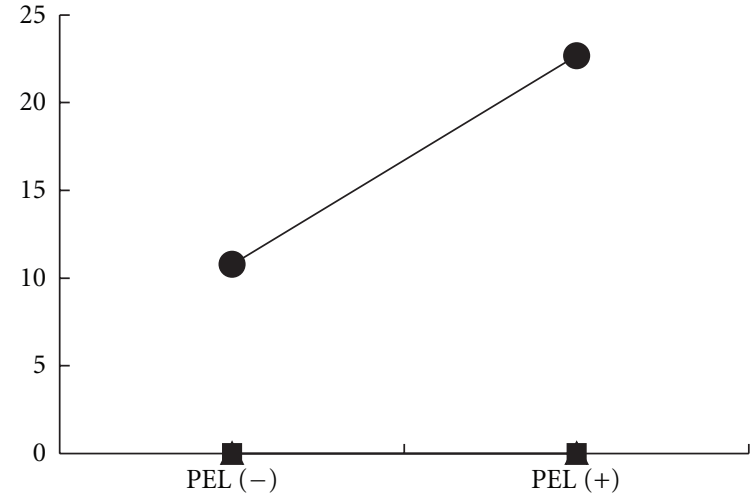

(a)

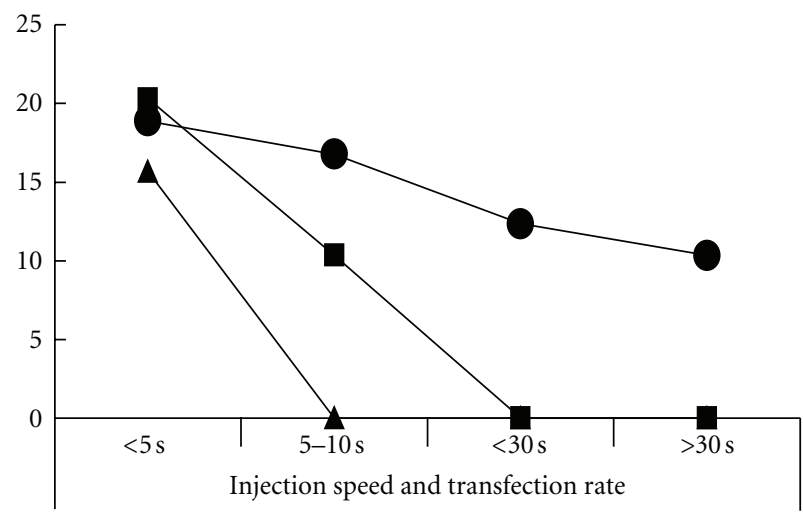

(c)

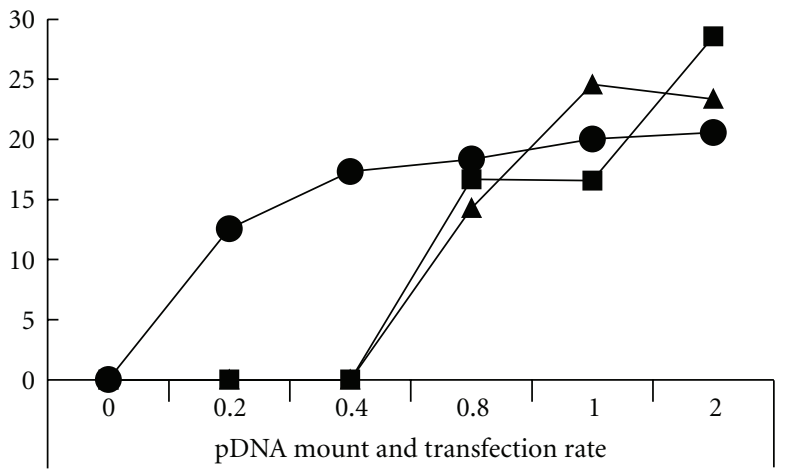

(b)

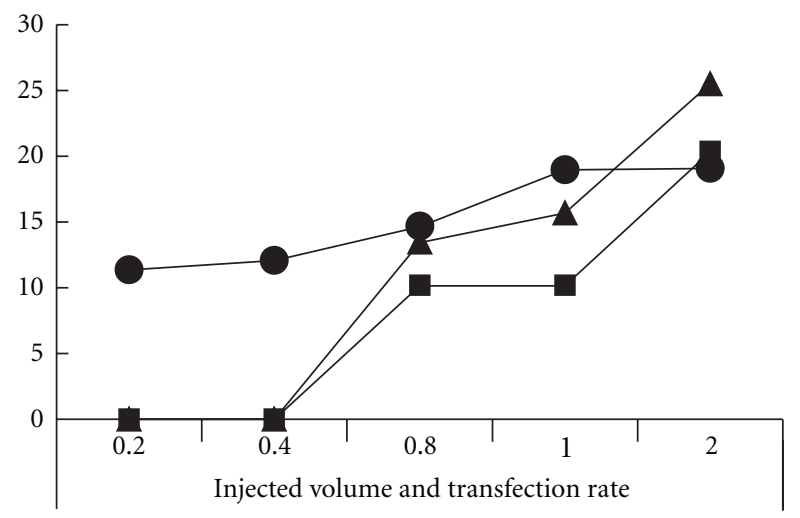

(d)

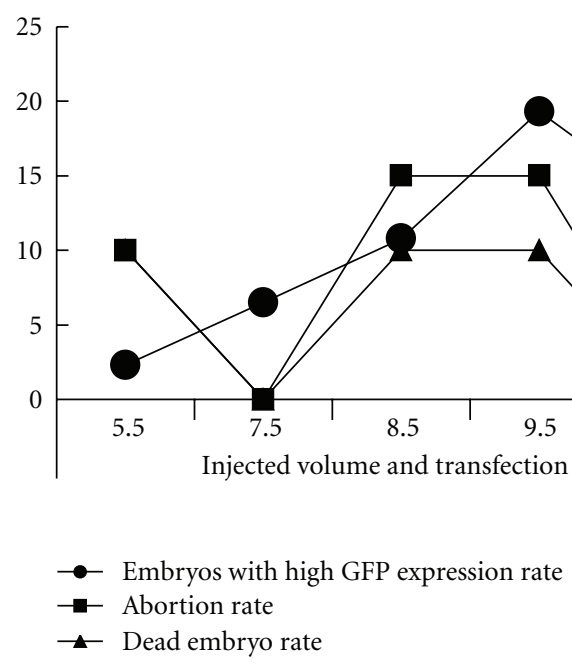

(e)

FIGURE 3: Factors affecting the shRNA deliver efficiency and toxicity on developing embryos in vivo. shRNA vector transfection rate was measured by GFP expression level, and the toxicity was assessed by pregnant mice abortion rate and dead embryo rate. GFP expression level and dead embryo rate were detected after treatment with plasmids for $48 \mathrm{~h}$, and pregnant mice abortion rate was detected at $48 \mathrm{~h}$ after injection. (a) Amount of PEI affects pDNA transfection rate and toxicity. $0.8 \mathrm{mg}$ of pSilencer4.1/Sry565 plasmid mixed with same amount of (PEI+) or without PEI (PEI-) diluted in $1.0 \mathrm{~mL} 5 \%$ glucose solution was injected into $9.5 \mathrm{dpc}$ pregnant mice tail vine in 10 seconds. (b) Effect of pDNA amount on transfection rate and toxicity. Certain amount of pSilencer4.1/Sry565 plasmids mixed with PEI, diluted in 1.0 mL of $5 \%$ glucose solution, were injected into $9.5 \mathrm{dpc}$ pregnant mice tail vine in 10 seconds. (c) Effect of injection speed on transfection rate and toxicity. Pregnant mice at $9.5 \mathrm{dpc}$ were intravenously injected with $0.8 \mathrm{mg}$ of plasmid DNA and PEI complex in $1.0 \mathrm{~mL}$ saline. The injection time was varied from 5 to $30 \mathrm{~s}$. (d) Effect of injection volume on transfection rate and toxicity. $0.8 \mathrm{mg}$ of plasmid DNA and PEI complex was diluted in 0.2 to $2.0 \mathrm{~mL} 5 \%$ glucose solution and injected into pregnant mice at $9.5 \mathrm{dpc}$. (e) Effects of injection time on transfection rate and toxicity. $0.8 \mathrm{mg}$ of plasmid DNA and PEI complex was diluted $1.0 \mathrm{~mL} 5 \%$ glucose solution and injected into pregnant mice various at $5.5 \mathrm{dpc}$ to $10.5 \mathrm{dpc}$. GFP expressions in embryos and dead embryo rate were detected at $11.5 \mathrm{dpc}$. Pregnant mice abortion rate was measured in $48 \mathrm{~h}$ after injection. 


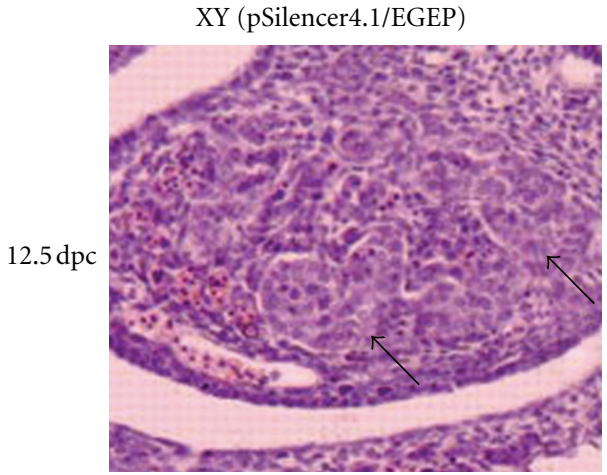

(a)

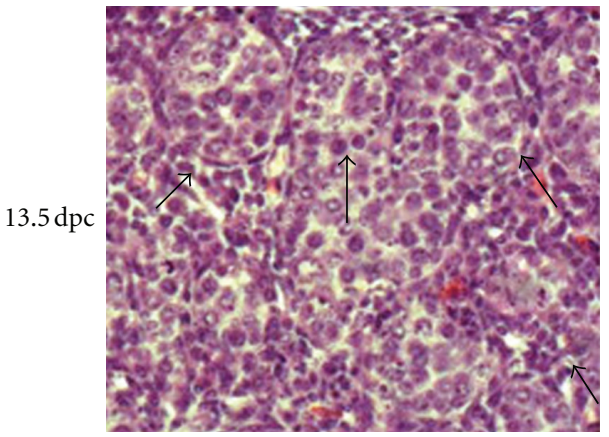

(d)

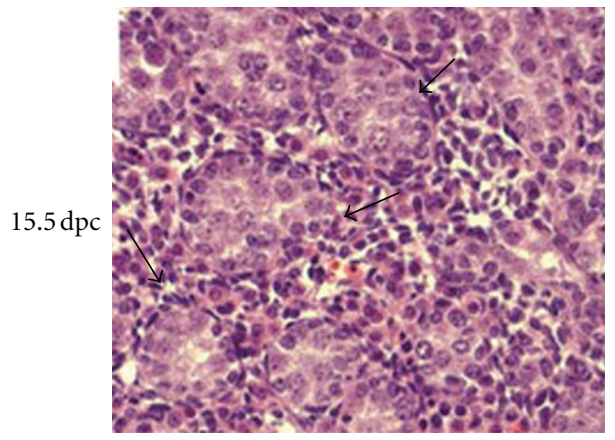

(g)



(b)

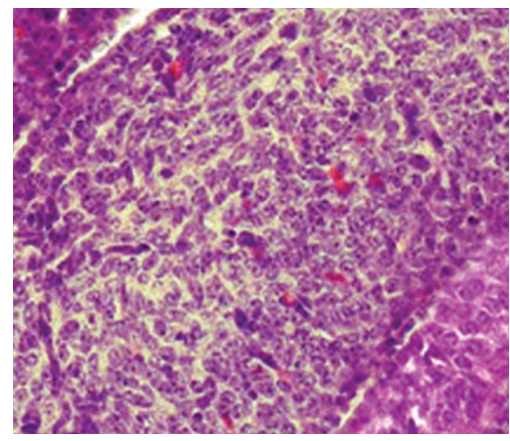

(e)

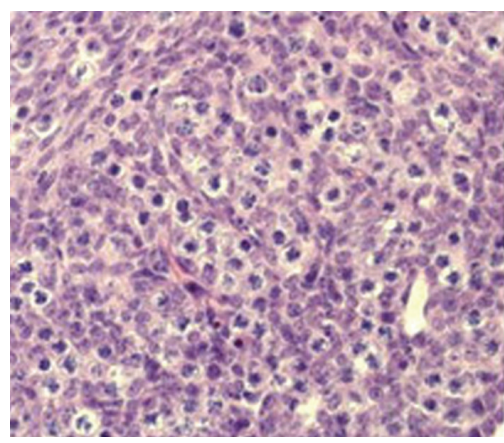

(h)

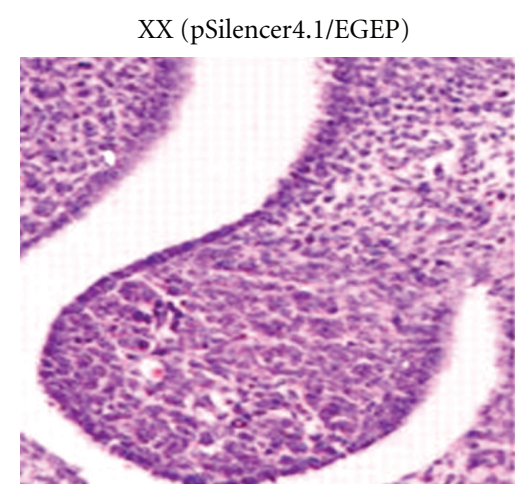

(c)

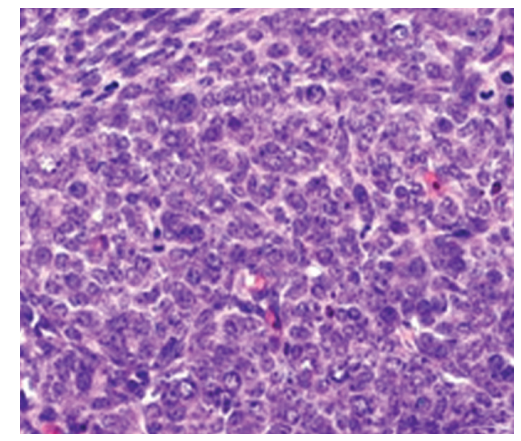

(f)

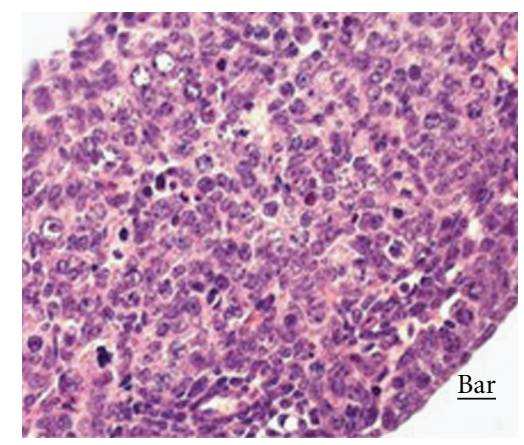

(i)

FIGURE 4: Feminization of male gonads following knock-down of Sry. Starting at $12.5 \mathrm{dpc}$, testis cords (arrows) are visible in the control plasmid pSilencer4.1-EGFP-treated XY male gonad (a); no signs of differentiation can be observed in the control females (c) and Sry knockdown (pSilencer4.1/Sry565 treated) male gonad (b). At $13.5 \mathrm{dpc}$, clearly visible testis cords appeared in control male gonads (d), whereas in Sry knocked-down male gonad no sign of differentiation was found (e), just like the control females (f). At $15.5 \mathrm{dpc}$, testis cords can be observed clearly in control males (g), While unorganized and no visible testis cords were found in Sry knocked-down male embryos' gonads (h), developing like the control female gonad (h). The photos were taken at transverse sections; bar $=50 \mu \mathrm{m}$.

However, there are a lot of factors affecting silencing efficiency in using HTV injection method to deliver shRNA into embryos through mother mouse; several relevant parameters have to be taken into consideration, including (i) siRNA protection, (ii) transfection efficacy, (iii) toxicity and absence of nonspecific effects, and (iv) convenient to carry out at various condition. (v) The ability of the transferring vectors to overcome numerous biological barriers after systemic administration to reach their target tissues/organs. In the present study, we investigated several factors which may influence the silence effects. We use a complex of shRNA expression plasmid and PEI to protect nucleic acid from nuclease degradation. Our results showed that low molecular weight PEIs were superior for gene transfer in vivo, and a proper amount of PEI mixed with pDNA is necessary to enhance transfection efficiency and to decrease toxicity. PEIs for siRNA delivery in vivo have been used in many models and recently they have been used in clinical therapy for lung cancer [43]. Our results show that PEIs are a kind of effective and safe medium for pDNA delivery in transplacental RNAi.

Previous study has shown that systemic delivery of pDNA based on high-pressure, large-volume tail vein injection could increase transfection efficacy. Our present study also revealed that large-volume and fast injection enhances 




(a)

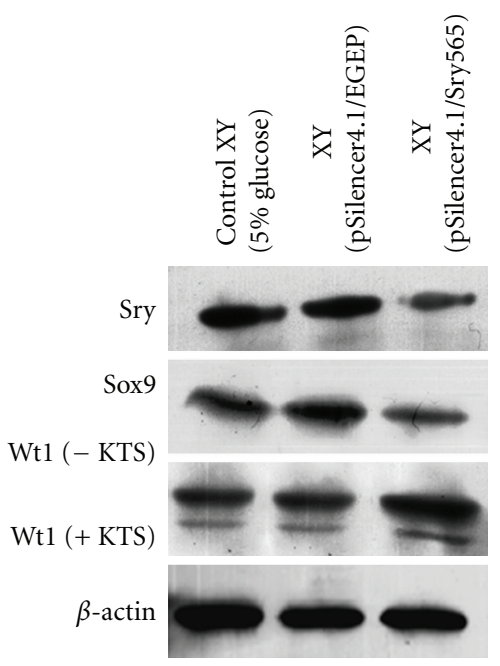

(b)

FIGURE 5: Effects of Sry silencing on gene expression in $11.5 \mathrm{dpc}$ male embryo gonads. The value of each gene expression level was divided to the $\beta$-actin expression level in Control males and was normalized as $100 \%$. The two-tail $t$-test was employed to statistically analyze the results: ${ }^{* *} P<0.01$

the gene transfer efficacy. Since the pregnant mice are more sensitive to the stresses, extremely large-volume and too fast injection will cause abortion occurrence. In the pregnant mice, proper volume and injection speed should be considered. Previous studies also confirmed that injection time have great relationship with the transfection efficiency; $8.5 \mathrm{dpc}$ is the optimum time to deliver plasmid DNA to developing embryos in mice [44]. It has also been reported that DNA-liposome complexes were trapped in the visceral endoderm prior to placenta development on $11.5 \mathrm{dpc}$ [45]. Others have also reported hemodynamic transfer of genes to the fetal compartment. For example, intravenous delivery of plasmid DNA to pregnant mice on $9.5 \mathrm{dpc}$ successfully immunized the fetuses against HIV-1 and influenza [46]. Similar results were obtained in the present study; when delivered pDNA complex with PEI on 5.5, 7.5, 8.5, 9.5, and $10.5 \mathrm{dpc}$, the peak level of pDNA expression was found in the $9.5 \mathrm{dpc}$ delivery group. The results indicated that delivery pDNA into fetus through pregnant mice at early stage of embryos development could not get the ideal results as delivery in the middle development stage.

One drawback using tail vein injection is that plasmid DNA is likely to be delivered to unintended maternal tissues. Since the liver has an expandable circulation and is easily transfected using intravenous delivery, this approach has been widely used in silencing genes in liver in pregnant females and neonates. Our present study showed that using certain volume, and injection speed, no obvious toxicity was found. Since the function of Sry is sex-related differentiation only, its expression in parent tissues does not affect the development of parent mice. This method would be very useful to target a gene expressed only in male/female embryos. The opposite sex litter mates could be served as a control for maternal effects.

A previous study has shown that Sry is necessary and sufficient for initiating testis determination. In the presence of Sry, the bipotential gonad anlagen differentiated into testes. While in its absence or mutation, the gonad develops into ovaries or ovotestis. Study using transgenic mice to knock-out Sry confirmed that XX mouse could develop into male embryo [19]. Further study revealed that expression levels of Sry are also important for its function. Sry expression level has to reach a certain threshold to induce testis development [37, 40]. Insufficient expression of Sry resulted in abnormal testis development of XY embryos. In fetuses of XY Gata4/Fog 2 null mutation mice, the Sry transcript levels were significantly reduced and resulted in abnormality in gonadgenesis. In addition, XY sex reversal was also found when the Sry expression level reduced to $\sim 25 \%$ of the wildtype [36]. In the present study, we found that Sry plays a key role in mouse testis determination. Silencing of Sry in embryos of genetic male mouse resulted in feminization of the gonads. Significant inhibition of Sox9 expression was found in Sry-silenced embryos. The results are consistent with previous study which confirmed that Sox 9 was regulated by Sry in gonad. Sox9 was upregulated by the transient expression of Sry specifically in Sertoli cell precursors [28].

Our study also revealed that WT1 expression was increased in Sry knockdown gonads. Wt1 plays an important role in the initial formation of the undifferentiated genital ridge and germ cells as well as the spermatogenesis $[47,48]$. Inactivation of the mouse Wt1 gene by gene knock out completely abolishes both renal and gonadal developments $[47,48]$. Studies have shown that Sry expression is in part regulated by $W t 1$. During embryogenesis, the Wt1 is initially expressed in intermediate mesoderm at $9.5 \mathrm{dpc}$ before the Sry expression, and Wt1 (-KTS) isoform binds and transactivates the human and pig Sry promoter in vitro $[34,49,50]$. However, there was another evidence to show that in mouse pluripotent conditions of cells, Wt1 expression is regulated by Sry [32]. In mouse ES cell line, Sry overexpression resulted in downregulated $W t 1$ expression 
[51]. In our present research, silencing Sry in developing embryos resulted in significantly upregulation of $W T 1$, and this is the first time to reveal that WT1 expression is regulated by Sry in vivo. It is possible to speculate that there exists a negative feedback mechanism between Wt1 and Sry. Wt1 might turn on and upregulated Sry expression and high level expression of Sry downregulates expression of Wt1 to keep Sry in a suitable level. Study is ongoing in our laboratory to address if overexpression of WT1 in developing embryo could result in downregulation of Sry expression.

\section{Conclusion}

In conclusion, transplacental RNAi can be used to knockdown of Sry gene during embryo sex differentiation in developing mouse embryos. The study revealed that knockingdown of Sry resulted in feminization of gonad development in mouse embryos, and the Sox 9 and Wt1 genes were directly regulated by Sry gene. Several factors influence the efficiency of transplacental RNAi; plasmid complex with PEI significantly enhances the deliver efficiency and the transfection efficiency is associated with the amount of plasmid DNA injection, injection time, injection speed, and volume. Transplacental RNAi could be implemented in developing embryos, and this approach provides an important technique of gene therapy in human sex-linked diseases.

\section{Acknowledgments}

The authors deeply appreciate Dr. Weihua Du, Fengtong Han, and Bing Liao of the institute of animal science of Chinese Academy of Agricultural Sciences for their kind help. This work was supported by the National Innovative GOMs Development Programs of China (Nos. 2009ZX08006-013B and 2009ZX08010-024B).

\section{References}

[1] G. J. Hannon, "RNA interference," Nature, vol. 418, no. 6894, pp. 244-251, 2002.

[2] D. M. Dykxhoorn, C. D. Novina, and P. A. Sharp, "Killing the messenger: short RNAs that silence gene expression," Nature Reviews Molecular Cell Biology, vol. 4, no. 6, pp. 457-467, 2003.

[3] S. M. Elbashir, J. Harborth, W. Lendeckel, A. Yalcin, K. Weber, and T. Tuschl, "Duplexes of 21-nucleotide RNAs mediate RNA interference in cultured mammalian cells," Nature, vol. 411, no. 6836, pp. 494-498, 2001.

[4] S. M. Elbashir, J. Harborth, K. Weber, and T. Tuschl, "Analysis of gene function in somatic mammalian cells using small interfering RNAs," Methods, vol. 26, no. 2, pp. 199-213, 2002.

[5] Z. Paroo and D. R. Corey, "Challenges for RNAi in vivo," Trends in Biotechnology, vol. 22, no. 8, pp. 390-394, 2004.

[6] N. Perrimon, J. Q. Ni, and L. Perkins, "In vivo RNAi: today and tomorrow," Cold Spring Harbor Perspectives in Biology, vol. 2, no. 8 , p. a003640, 2010.

[7] C. Coutelle, A. M. Douar, W. H. Colledge, and U. Froster, "The challenge of fetal gene therapy," Nature Medicine, vol. 1, no. 9, pp. 864-866, 1995.
[8] H. S. Baldwin, C. Mickanin, and C. Buck, "Adenovirusmediated gene transfer during initial organogenesis in the mammalian embryo is promoter-dependent and tissuespecific," Gene Therapy, vol. 4, no. 11, pp. 1142-1149, 1997.

[9] K. M. L. Gaensler, G. Tu, S. Bruch et al., "Fetal gene transfer by transuterine injection of cationic liposome-DNA complexes," Nature Biotechnology, vol. 17, no. 12, pp. 1188-1192, 1999.

[10] A. M. Douar, S. Adebakin, M. Themis, A. Pavirani, T. Cook, and C. Coutelle, "Foetal gene delivery in mice by intra-amniotic administration of retroviral producer cells and adenovirus," Gene Therapy, vol. 4, no. 9, pp. 883-890, 1997.

[11] A. Türkay, T. L. Saunders, and K. Kurachi, "Intrauterine gene transfer: gestational stage-specific gene delivery in mice," Gene Therapy, vol. 6, no. 10, pp. 1685-1694, 1999.

[12] F. Liu, Y. K. Song, and D. Liu, "Hydrodynamics-based transfection in animals by systemic administration of plasmid DNA," Gene Therapy, vol. 6, no. 7, pp. 1258-1266, 1999.

[13] G. Zhang, V. Budker, and J. A. Wolff, "High levels of foreign gene expression in hepatocytes after tail vein injections of naked plasmid DNA," Human Gene Therapy, vol. 10, no. 10, pp. 1735-1737, 1999.

[14] A. P. McCaffrey, L. Meuse, T. T. T. Pham, D. S. Conklin, G. J. Hannon, and M. A. Kay, "RNA interference in adult mice," Nature, vol. 418, no. 6893, pp. 38-39, 2002.

[15] E. Song, S. K. Lee, J. Wang et al., "RNA interference targeting Fas protects mice from fulminant hepatitis," Nature Medicine, vol. 9, no. 3, pp. 347-351, 2003.

[16] D. L. Lewis, J. E. Hagstrom, A. G. Loomis, J. A. Wolff, and H. Herweijer, "Efficient delivery of siRNA for inhibition of gene expression in postnatal mice," Nature Genetics, vol. 32, no. 1, pp. 107-108, 2002.

[17] T. E. Gratsch, L. S. De Boer, and K. S. O'Shea, "RNA inhibition of BMP-4 gene expression in postimplantation mouse embryos," Genesis, vol. 37, no. 1, pp. 12-17, 2003.

[18] K. S. O'Shea, L. S. De Boer, N. A. Slawny, and T. E. Gratsch, "Transplacental RNAi: deciphering gene function in the postimplantation- staged embryo," Journal of Biomedicine and Biotechnology, vol. 2006, Article ID 18657, 2006.

[19] P. Koopman, J. Gubbay, N. Vivian, P. Goodfellow, and R. Lovell-Badge, "Male development of chromosomally female mice transgenic for Sry," Nature, vol. 351, no. 6322, pp. 117121, 1991.

[20] A. H. Sinclair, P. Berta, M. S. Palmer et al., "A gene from the human sex-determining region encodes a protein with homology to a conserved DNA-binding motif," Nature, vol. 346, no. 6281, pp. 240-244, 1990.

[21] K. H. Albrecht and E. M. Eicher, "Evidence that Sry is expressed in pre-Sertoli cells and Sertoli and granulosa cells have a common precursor," Developmental Biology, vol. 240, no. 1, pp. 92-107, 2001.

[22] D. Wilhelm, F. Martinson, S. Bradford et al., "Sertoli cell differentiation is induced both cell-autonomously and through prostaglandin signaling during mammalian sex determination," Developmental Biology, vol. 287, no. 1, pp. 111-124, 2005.

[23] A. Hacker, B. Capel, P. Goodfellow, and R. Lovell-Badge, "Expression of Sry, the mouse sex determining gene," Development, vol. 121, no. 6, pp. 1603-1614, 1995.

[24] Y. W. A. Jeske, J. Bowles, A. Greenfield, and P. Koopman, "Expression of a linear Sry transcript in the mouse genital ridge," Nature Genetics, vol. 10, no. 4, pp. 480-482, 1995.

[25] V. P. I. Vidal, M. C. Chaboissier, D. G. De Rooij, and A. Schedl, "Sox9 induces testis development in XX transgenic mice," Nature Genetics, vol. 28, no. 3, pp. 216-217, 2001. 
[26] C. E. Bishop, D. J. Whitworth, Y. Qin et al., "A transgenic insertion upstream of Sox 9 is associated with dominant XX sex reversal in the mouse," Nature Genetics, vol. 26, no. 4, pp. 490-494, 2000.

[27] Y. Qin and C. E. Bishop, "Sox9 is sufficient for functional testis development producing fertile male mice in the absence of Sry," Human Molecular Genetics, vol. 14, no. 9, pp. 1221-1229, 2005.

[28] R. Sekido, I. Bar, V. Narváez, G. Penny, and R. Lovell-Badge, "SOX9 is up-regulated by the transient expression of SRY specifically in Sertoli cell precursors," Developmental Biology, vol. 274, no. 2, pp. 271-279, 2004.

[29] C. Englert, "WT1-more than a transcription factor?" Trends in Biochemical Sciences, vol. 23, no. 10, pp. 389-393, 1998.

[30] A. Hammes, J. K. Guo, G. Lutsch et al., "Two splice variants of the wilms' tumor 1 gene have distinct functions during sex determination and nephron formation," Cell, vol. 106, no. 3, pp. 319-329, 2001.

[31] M. Ito, M. Miyagishi, C. Murata et al., "Down-regulation of endogenous Wt1 expression by Sry transgene in the murine embryonic mesonephros-derived M15 cell line," Journal of Reproduction and Development, vol. 52, no. 3, pp. 415-427, 2006.

[32] Y. Toyooka, S. S. Tanaka, O. Hirota et al., "Wilms' tumor suppressor gene (WT1) as a target gene of SRY function in a mouse ES cell line transfected with SRY," International Journal of Developmental Biology, vol. 42, no. 8, pp. 1143-1151, 1998.

[33] G. J. Bouma, K. H. Albrecht, L. L. Washburn, A. K. Recknagel, G. A. Churchill, and E. M. Eicher, "Gonadal sex reversal in mutant Dax1 XY mice: a failure to upregulate Sox9 in preSertoli cells," Development, vol. 132, no. 13, pp. 3045-3054, 2005.

[34] N. Pilon, I. Daneau, V. Paradis et al., "Porcine SRY promoter is a target for steroidogenic factor 1," Biology of Reproduction, vol. 68, no. 4, pp. 1098-1106, 2003.

[35] M. Bielinska, A. Seehra, J. Toppari, M. Heikinheimo, and D. B. Wilson, "GATA-4 is required for sex steroidogenic cell development in the fetal mouse," Developmental Dynamics, vol. 236, no. 1, pp. 203-213, 2007.

[36] S. G. Tevosian, K. H. Albrecht, J. D. Crispino, Y. Fujiwara, E. M. Eicher, and S. H. Orkin, "Gonadal differentiation, sex determination and normal Sry expression in mice require direct interaction between transcription partners GATA4 and FOG2," Development, vol. 129, no. 19, pp. 4627-4634, 2002.

[37] C. M. Nagamine, K. I. Morohashi, C. Carlisle, and D. K. Chang, "Sex reversal caused by Mus musculus domesticus Y chromosomes linked to variant expression of the testisdetermining gene Sry," Developmental Biology, vol. 216, no. 1, pp. 182-194, 1999.

[38] N. Wu, X. K. Lin, B. Liao, W. H. Du, F. T. Han, and J. H. Zhao, "Effect of Sry silencing by siRNA on the expression of sex determining genes in mouse embryos," Yi Chuan, vol. 30, no. 2, pp. 195-202, 2008.

[39] J. F. Lambert, B. O. Benoit, G. A. Colvin, J. Carlson, Y. Delville, and P. J. Quesenberry, "Quick sex determination of mouse fetuses," Journal of Neuroscience Methods, vol. 95, no. 2, pp. 127-132, 2000.

[40] K. H. Albrecht, M. Young, L. L. Washburn, and E. M. Eicher, "Sry expression level and protein isoform differences play a role in abnormal testis development in C57BL/6J mice carrying certain Sry alleles," Genetics, vol. 164, no. 1, pp. 277$288,2003$.
[41] G. Mellitzer, M. Hallonet, L. Chen, and S. L. Ang, "Spatial and temporal 'knock down' of gene expression by electroporation of double-stranded RNA and morpholinos into early postimplantation mouse embryos," Mechanisms of Development, vol. 118, no. 1-2, pp. 57-63, 2002.

[42] X. Coumoul and C. X. Deng, "RNAi in mice: a promising approach to decipher gene functions in vivo," Biochimie, vol. 88, no. 6, pp. 637-643, 2006.

[43] M. Günther, J. Lipka, A. Malek, D. Gutsch, W. Kreyling, and A. Aigner, "Polyethylenimines for RNAi-mediated gene targeting in vivo and siRNA delivery to the lung," European Journal of Pharmaceutics and Biopharmaceutics, vol. 77, no. 3, pp. 438449, 2011.

[44] M. Tsukamoto, T. Ochiya, S. Yoshida, T. Sugimura, and M. Terada, "Gene transfer and expression in progeny after intravenous DNA injection into pregnant mice," Nature Genetics, vol. 9, no. 3, pp. 243-248, 1995.

[45] N. Kikuchi, S. Nakamura, M. Ohtsuka, M. Kimura, and M. Sato, "Possible mechanism of gene transfer into early to midgestational mouse fetuses by tail vein injection," Gene Therapy, vol. 9, no. 22, pp. 1529-1541, 2002.

[46] J. W. Smith and M. R. Tully, "Midwifery management of breastfeeding: using the evidence," Journal of Midwifery and Women's Health, vol. 46, no. 6, pp. 423-438, 2001.

[47] J. A. Kreidberg, H. Sariola, J. M. Loring et al., "WT-1 is required for early kidney development," Cell, vol. 74, no. 4, pp. 679-691, 1993.

[48] A. W. Moore, L. McInnes, J. Kreidberg, N. D. Hastie, and A. Schedl, "YAC complementation shows a requirement for Wt1 in the development of epicardium, adrenal gland and throughout nephrogenesis," Development, vol. 126, no. 9, pp. 1845-1857, 1999.

[49] R. Shimamura, G. C. Fraizer, J. Trapman, Y. F. C. Lau, and G. F. Saunders, “The Wilms' tumor gene WT1 can regulate genes involved in sex determination and differentiation: SRY, Mullerian-inhibiting substance, and the androgen receptor," Clinical Cancer Research, vol. 3, no. 12, pp. 2571-2580, 1997.

[50] A. Hossain and G. F. Saunders, "The human sex-determining gene SRY is a direct target of WT1," Journal of Biological Chemistry, vol. 276, no. 20, pp. 16817-16823, 2001.

[51] M. Ito, M. Miyagishi, C. Murata et al., "Down-regulation of endogenous Wt1 expression by Sry transgene in the murine embryonic mesonephros-derived M15 cell line," Journal of Reproduction and Development, vol. 52, no. 3, pp. 415-427, 2006. 

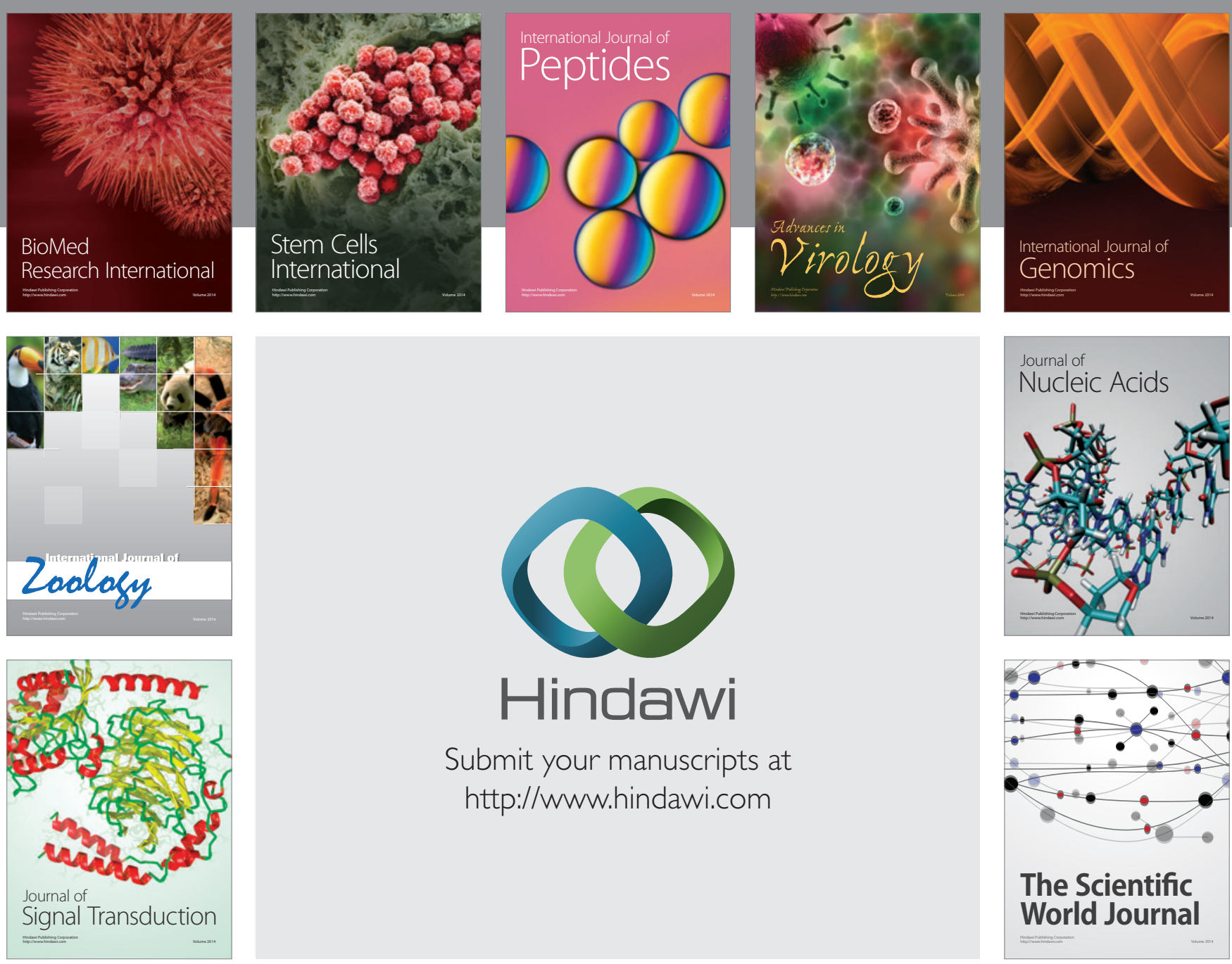

Submit your manuscripts at

http://www.hindawi.com
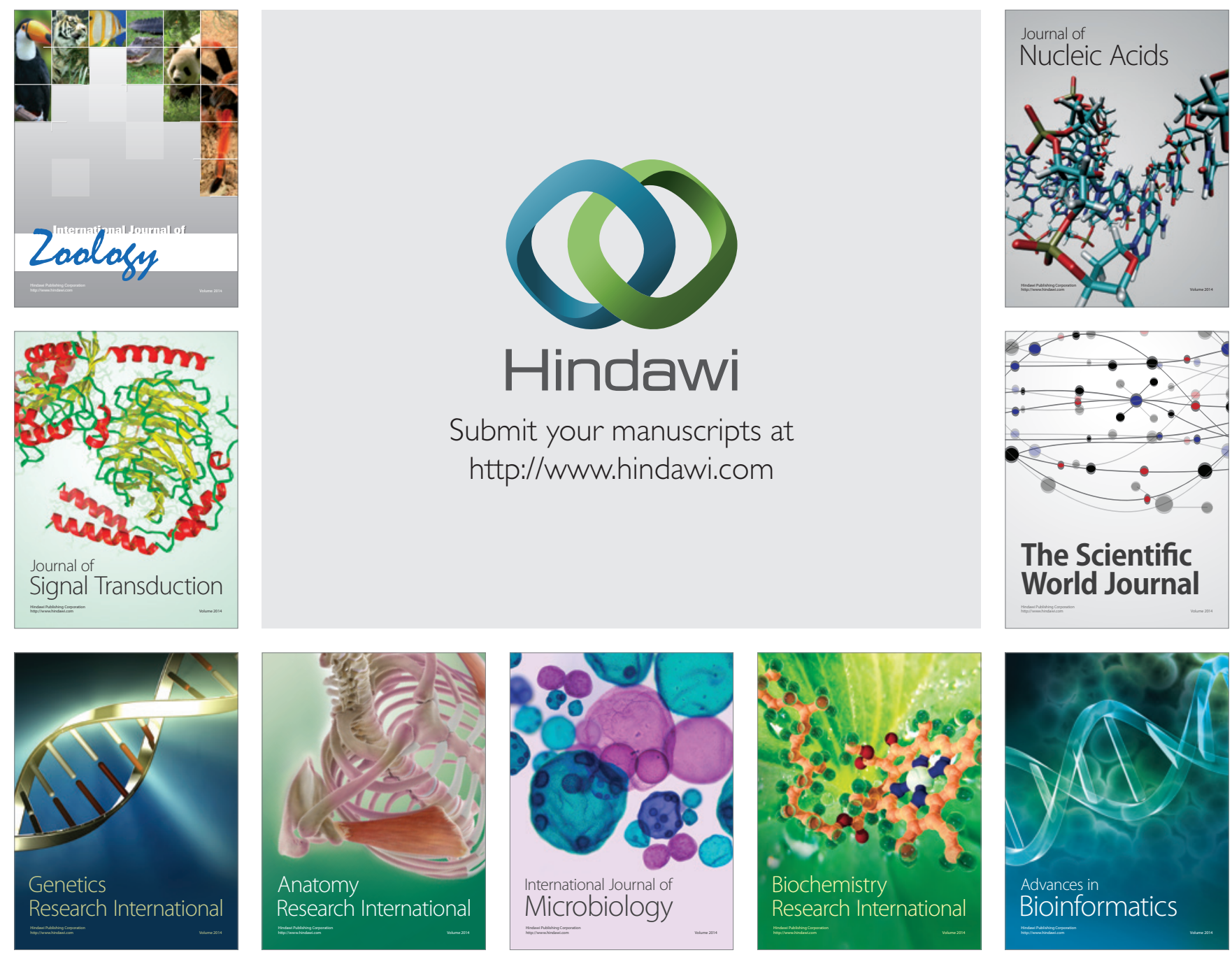

The Scientific World Journal
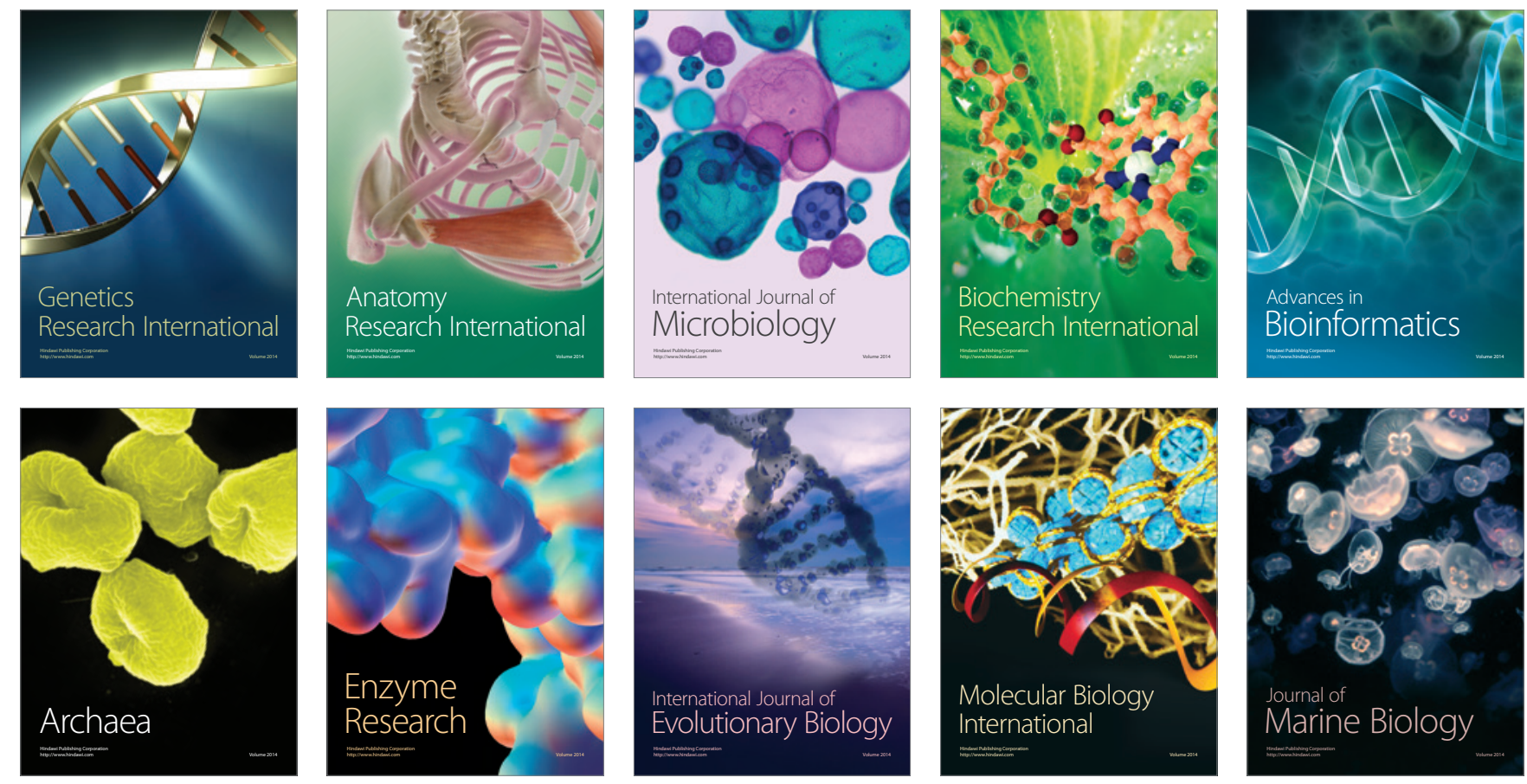